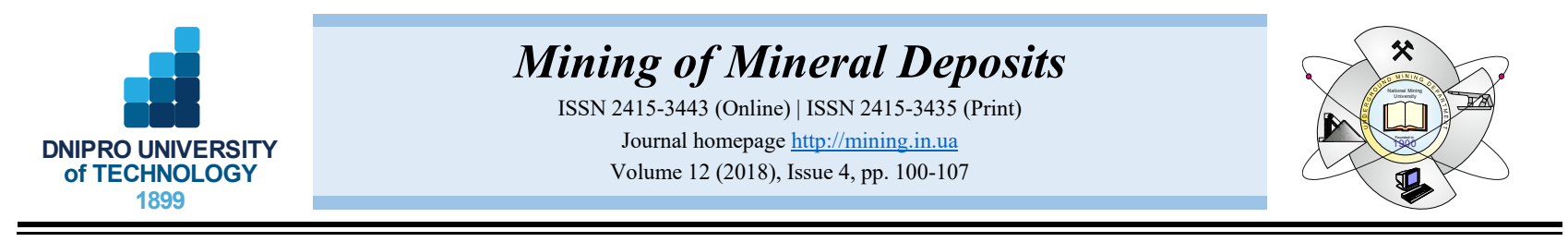

\title{
HARMONIZATION OF MODELING SYSTEMS FOR ASSESSING THE ELECTRIC-POWER CONSUMPTION LEVELS AT MINING ENTERPRISES
}

\author{
I. Sinchuk ${ }^{1 *}$ \\ ${ }^{1}$ Kryvyi Rih National University, Kryvyi Rih, Ukraine \\ *Corresponding author: e-mail Beridzet2016@gmail.com, tel. +380989876795
}

\begin{abstract}
Purpose. The purpose of the work is to study the system corporate features of electric-power consumption systems, the formation of applied scientific and methodological support, as well as economic and mathematical modeling tools to analyse the cost characteristics of the electric-power consumption.

Methods. The research is based on the use of laws, patterns and categorical set. In the course of scientific research, the general scientific methods were used (comparison, generalization, analogue method, structural analysis and synthesis), methods of logical-theoretical analysis and special economic-mathematical methods. The official documents that reflect and regulate certain aspects of the power consumption system in the acquisition, processing and presentation of information were the normative basis of research. The materials of scientific conferences and seminars, the resources of the global Internet information system, the information from the State Statistics Service of Ukraine were used as information sources. The theoretical basis of research is confirmed by scientific works of domestic and foreign researchers in the field of power supply in a transition economy. The complex of regression and index methods, as well as models of electric-power consumption analysis are used to determine the transformational changes in the components of electric-power consumption.
\end{abstract}

Findings. The parameters have been analysed of electric-power consumption in iron-ore enterprises of the Kryvyi Rih region. The process has been investigated of forming a system of models for solving the problem of the cost characteristics optimization of electric-power consumption. The system corporate features have been determined of the power consumption systems in iron-ore enterprises of the Kryvyi Rih region. The tools set has been formed of economic and mathematical modelling in order to analyse and assess the cost indicators of power consumption systems. The harmonization of modelling methods made it possible to determine the cost characteristics and prove the rationality of using the models, calculate the effective resources assignment, and make recommendations in accordance with rational management decisions on the formation of electric-power consumption.

Originality. An innovative integrated approach to the formation of corporate models of electric-power supply systems has been proposed, which uses the index methodology in combination with the least modules methods. This approach allows to optimize electric-power costs and ensure rational management of electric-power consumption.

Practical implications. The formation of corporate models is the basis for further research and the construction of multifactorial regression models, as well as models to predict the electric-power consumption. Practical experience in the use of the proposed methodology has proven its effectiveness in making management decisions to ensure optimal electric-power consumption characteristics.

Keywords: modelling, electric-power consumption, indicators, resources, enterprise

\section{INTRODUCTION}

One of the most important conditions for an effective economic growth is to improve the management of electric-power consumption, to construct a rational structure of the cost components of power supply. To ensure the effective functioning and development of the management mechanism for electric-power consumption, it is advisable to use an adequate system of models that takes into account the complexity and high dynamics of the electricpower supply systems at mining enterprises, and provides the ability to conduct relevant research (Sinchuk, Guzov, Parkhomenko, \& Rozen, 2013; Sinchuk et al., 2016).

Deepening the processes of market transformations in Ukraine increases the dependence of their performance on the proportions of the energy resources distribution in 
the regions' economy, the dynamics of their long-term balance. Undoubtedly, the development and use of alternative energy sources is of justifiable scientific and practical interest. The studies cited in (Farret, \& Simoes, 2006), point out that the problem of using such electricpower is a necessary measure.

The formal analytical models of electric-power supply systems are an information display of real objects, therefore their analysis is undoubtedly closely related to the management processes of electric-power consumption, which can be considered a set of operations and information conversion procedures to ensure rational management of energy resources. Currently, the use of a formal and analytical methodology provides a unique insight into the basics, models and methods of multicriteria decision-making assistance (Mareschal, 1988). The incompatibility principle, formulated by L. Zadeh, according to which with an increase in the dimensionality and complexity of a system, its modeling is significantly complicated by means of well-known mathematical ratios (Saade \& Diab, 2000). The development of high-voltage semiconducting technologies continues to have a significant impact on the progress in developed power electronic devices used to optimize the operation and the efficient management of smart power grids, and is being outlined in (Zeleny, 1982). In this sense, the connection between the formalized decision-making methods (with the use of computer and mathematical analysis) and human judgment based on intuition, experience and 'professional understanding' is of particular interest (Bayoumi, 2015). When solving the problem of formal analytical analysis of electric-power consumption levels, there is a real need for systematic monitoring of electric-power consumption levels. The harmonization of the simulation results will allow to determine the effective distribution of energy resources, to conduct a predictive analysis of resource provision and to make recommendations in accordance with the rational management decisions in electric-power consumption.

The scientific works of such scholars as V.O. Dzenis, O.O. Dzenis (Dzenis \& Dzenis, 2011), T. Vasyl'tsiv (Vasyl'tsiv, 2008), A. Tkachenko (Tkachenko \& Marchenko, 2014), I. Moiseienko (Moiseienko, Revak, \& Demchyshyn, 2013), and others are devoted to theoretical and methodological support of the processes of modeling and forecasting the production systems in general and electric-power supply systems under the conditions of transformational changes. They studied the issues of economic and mathematical modeling of certain aspects of the industry's potential, formulated the stages of the selection process and the formation of an enterprise development strategy. The conceptual approaches to the complex of economic and mathematical models for assessing and analysing the performance of economic systems in the region and country, based on models of intersectoral balance, have been proposed by the scientists B.V. Dmytryshyn, V.F. Hamalij (Dmytryshyn \& Hamalii, 2013). O.V. Cherevko, while studying the causeand-effect relationships and patterns of social and economic processes, used a multidimensional correlation and regression analysis of the territorial differentiation of investment climate levels of regions, which allowed to represent each region as a set of parameters, which are interpreted as coordinates of a point in a multidimensional space (Cherevko, 2007). The comprehensive scientific work of O.K. Yelisieieva (Yelisieieva, 2011) is devoted to modeling the management of social and economic systems, which represents the conceptual provisions for managing the development of social and economic systems based on mechanisms of integral type, management algorithms, models and technologies. The work of L.A. Burkova (Burkova, 2015) represents the recommendations on theoretical and methodological provisions, tools and practical recommendations for assessing the economic performance of enterprises, which became the basis for constructing the corresponding models. Among the domestic scientific papers, the works of A.V.Cherniavskyi, E.O. Kulikova should be mentioned (Cherniavskyi \& Kulikova, 2011), which have theoretically investigated the possibility of forecasting the electric-power consumption with the use of an algorithm of the Holt-Winters method, identified the main parameters affecting the assessment of the calculation results accuracy of predictive values of electric-power consumption. V.P. Rosen and L.V. Davydenko have studied the possibility of using the artificial neural networks. The most informative technological parameters of mine are used as input parameters of the neural network (Rozen \& Davydenko, 2010). The studies of (Sukhorukov \& Kharazishvili, 2012) are devoted to the issues about the rationality of the strategy for the power systems development.

Undoubtedly, the development of electric-power consumption systems is the basis for the development of domestic electric-power industry, so it should be based on the principles of ability to adapt to internal and external transformational changes.

The constant variability of competitive advantages requires a corresponding adjustment of the management system, primarily through the introduction of corporate analysis of electric-power consumption systems. Therefore, the introduction of the principles of the optimal distribution of energy resources is becoming more and more relevant.

The insufficient knowledge of this problem has led to the importance of and the need for further research. First of all, it concerns the modelling of the cost components of electric-power supply systems to study thoroughly the use of formalized methods with the purpose of implementing the rational management of the electric-power consumption at mining enterprises.

The purpose of the article is to study the cost characteristics of electric-power consumption systems, the formation of applied scientific and methodological support, as well as tools for mathematical modeling in order to analyse and assess the indicators of electric-power consumption systems.

\section{RESEARCH METHODOLOGY}

An integrated assessment of electric-power supply systems at mining enterprises is a quite complex task and essential in ensuring the stable development of the power system. The determination of such assessments should be carried out on the basis of a system of models. One of the basic principles of electric-power consumption manage- 
ment is the principle of optimality. The complexity of the power system fundamentally excludes the complete formalization of such systems, therefore, two subsystems are distinguished in them: the first subsystem is mostly formalized, the second one is mostly non-formalized. The second subsystem sets the external parameters for the formalized one and fixes the legitimacy of its certain procedures. Effective formalization of the electric-power supply system provides the possibility of external addition of it to its minimum, which is conditioned by the achieved level of study of such a system and its interaction with the environment. This can be accomplished with a systemic approach to the description of objects, when the formalization is a system of models interconnected by direct and reverse communication links (Stetsenko, 2010; Sinchuk et al., 2018).

In the process of research the general scientific research methods were used: comparison - for determining and analysing the difference between the actual and planned indicators of electric-power consumption levels. The analogue method was applied in the process of analysing the index methodology in terms of the implementation of its main provisions to the formation of a model for assessing the electric-power consumption levels. The basic principles of the method of logical-theoretical analysis form the basis for the construction of a scientific and practical logic for representing the research results. The use of economic and mathematical methods made it possible, on the basis of the harmonization of the optimization model and index modelling, to determine the possibility of applying the analytical methods to analyse the cost characteristics of electric-power consumption levels at mining enterprises.

\section{MATHEMATICAL REPRESENTATION OF ELECTRIC-POWER CONSUMPTION SYSTEM}

Any industrial electric-power supply system provides for daily planned targets, as well as monitoring the actual daily volume and cost of electric-power. What is more, the actual daily volumes and prices of electric-power vary in a stochastic manner. At the same time, it is obvious that the total cost of electric-power per month should not significantly differ from the planned one. Naturally, the actual prices during the month should also not significantly differ from the planned prices, which is associated with the ability to provide electric-power. Mathematically, this task is formulated as follows:

$$
\begin{aligned}
& \max _{1 \leq i \leq n}\left|C_{i}^{a}-C_{i}^{p}\right| \rightarrow \min ; \\
& \sum_{i=1}^{n} C_{i}^{p} \cdot g_{i}^{p}=S^{p} \\
& \sum_{i=1}^{n} C_{i}^{a} \cdot g_{i}^{a} \geq S^{p}
\end{aligned}
$$

where:

$C_{i}^{a}, C_{l}^{p}$ - the actual and planned prices of daily electric-power consumption, respectively, $(i=1,2, \ldots n)$;

$g_{i}{ }^{a}, g_{i}^{p}$ - the actual and planned daily volumes of consumed electric-power, respectively; $n$ - the number of days in a month;

$C^{p}$ - the planned cost of consumed electric-power per month.

The condition (1) specifies that the actual and planned prices for the daily consumed electric-power should not be significantly different, this is connected with the production process. The condition (2) determines the planned monthly electric-power cost. The condition (3) specifies that the actual cost of electricpower per month should be no less than planned.

It should be noted that the daily planned electricpower cost is determined by the formula:

$C_{i}^{p} \cdot g_{i}^{p}=S_{i}^{p}$

Then the restriction for the actual cost of a daily consumed electric-power can be written as follows:

$C_{i}^{a} \cdot g_{i}^{a} \geq S_{i}^{p},(i=1,2, \ldots n)$.

Taking into account (4), according to (5), we obtain the restriction on the value of daily actual price:

$C_{i}^{a}=\frac{S_{i}^{p}}{g_{i}},(i=1,2, \ldots n)$.

Thus, to meet the condition (1), the value of the daily actual price should be minimal, that is:

$\min C_{i}^{a}=\frac{S_{i}^{p}}{g_{i}^{a}},(i=1,2, \ldots n)$.

The disadvantage of the obtained formula (7) in that it is necessary to know the planned cost for electricpower consumed every day.

As one possible way to avoid this complication, the construction of a regression dependence is proposed, the structure of which is determined by the formula (7):

$C^{a}=\frac{a}{g^{a}}$

where:

$a-$ the required parameter.

Taking into account (8), the solution of the problem can be written in the form.

Condition (1) is converted to the form:

$F(a)=\max _{1 \leq i \leq n}\left|C_{i}^{p}-\frac{a}{g_{i}^{a}}\right| \rightarrow \min$.

The condition (3), with account of (8), takes the form:

$a \geq=\frac{1}{n} S^{p}$.

Thus, to solve the problem, it is necessary to minimize the parameter $a$, according to the condition (9), with account of the restriction (10).

It should be noted that this problem can be solved in a simpler setting, when replacing the condition (9) with the quadratic criterion: 
$F(a)=\sum_{i=1}^{n}\left(C_{i}^{p}-\frac{a}{g_{i}^{a}}\right) \rightarrow \min _{a}$.

To implement (11), we use the necessary condition for the extremum existence $F^{\prime}(a)=0$, then:

$a=\frac{\sum_{i=1}^{n} C_{i}^{p}}{\sum_{i=1}^{n} \frac{1}{g_{i}^{a}}}$.

The value (12) determines the optimal value of the parameter at which the functional (11) reaches a minimum. However, it is necessary to take into account the restrictions (10). Consider the solution to problem (1), (2), (3), according to the data shown in Figure 1.

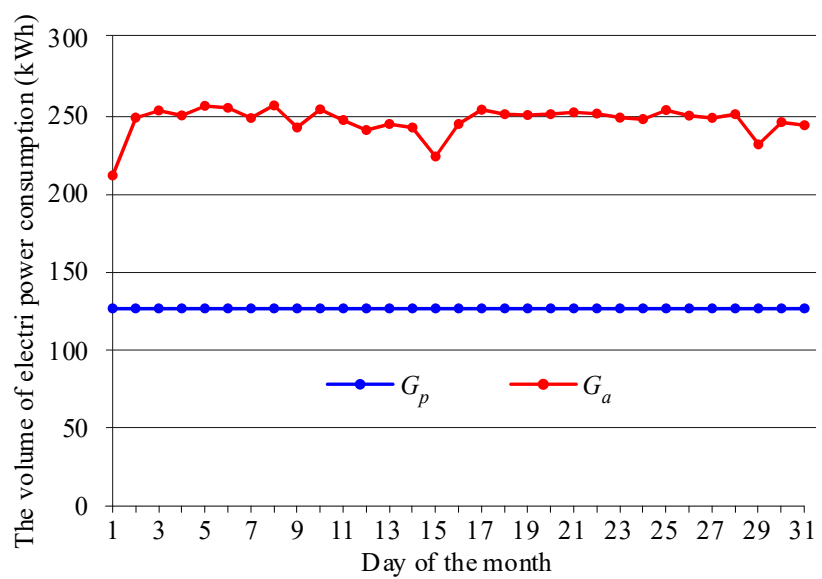

Figure 1. Statistics of electric-power data No axes signatures (they can be written here as the drawings will still be reissued under the style of the journal): $G_{p}-$ the volume of daily planned electric-power consumption $(\mathrm{kWh}) ; \mathrm{G}_{a}$ - the volume of daily actual electricpower consumption $(\mathrm{kWh})$

First of all, we find the planned cost of electric-power consumed per month:

$$
S^{p}=\sum_{i=1}^{30} C_{i}^{p} \cdot g_{i}^{p}=240790.6 .
$$

According to (13), the formulation of the problem (9), (10) takes the form:

$$
F(a)=\max _{1 \leq i \leq 30}\left|C_{i}^{p}-\frac{a}{g_{i}^{a}}\right| \rightarrow \min _{a} .
$$

$a \geq 8026.35$.

\section{RESULTS AND DISCUSSION}

Figure 2 represents a graphical solution of the problem (14), (15). According to Figure 1, the smallest functional value, equal to $F=11.5$, is achieved at $a=7500$. However, this value does not satisfy the restriction (15). Therefore, the optimal value is $a=8026.35$. Then the maximum value of deviation $F(8026.35)=17.07$.

Figure 3 shows the graphs of dependences of actual, planned and optimal prices during the month.

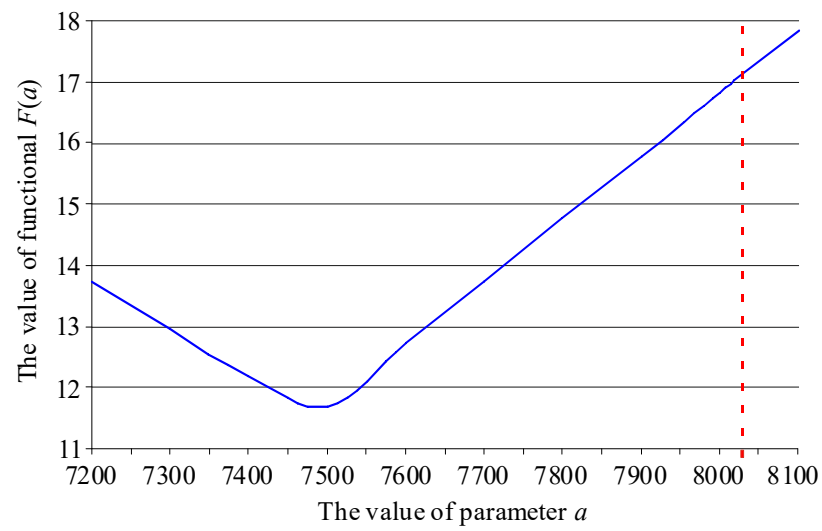

Figure 2. Graphic representation of the problem (14), (15) solution

In turn, Figure 3 shows graphs of the deviation of actual and optimal prices from planned within a month. Analysis of the graphs, represenred in Figure 3 and 4, shows that the optimal price values of the consumed electric-power, found by solving the problem (14), (15), have smaller deviations from the planned price values.

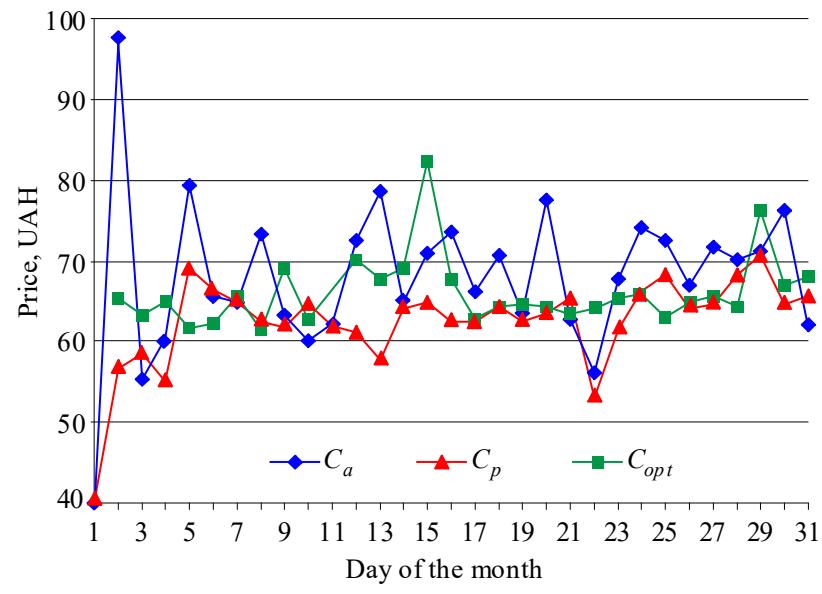

Figure 3. Graphs of dependence on time of prices for the consumed electric-power: $C_{a}$-actual price, hrn; $C_{p}$-planned price, hrn; $C_{\text {opt }}$-optimal price, hrn

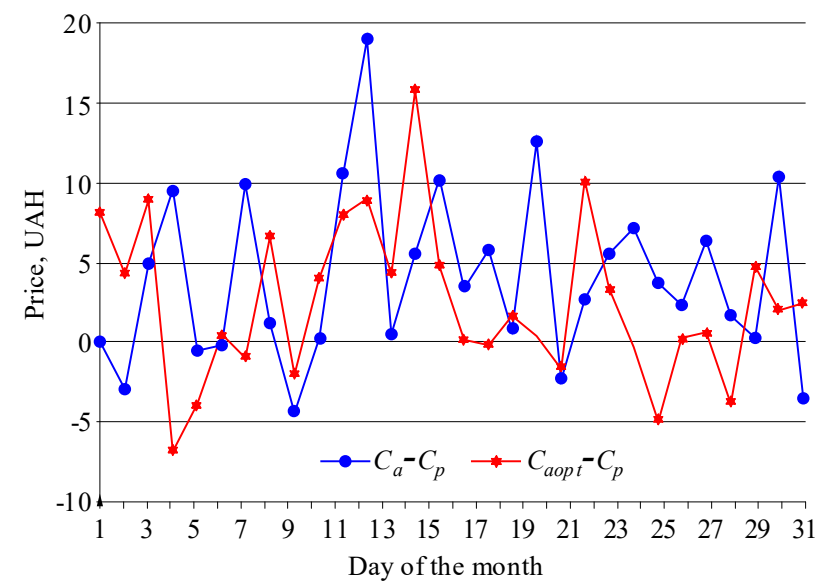

Figure 4. Graphs of changes in the deviation of price for the consumed electric-power from the planned one during the month: $C_{a}-C_{p}-$ the deviation in the actual price from the planned, hrn; $C_{o p t}-C_{p}-$ the deviation in the optimal price from the planned, hrn 
If to use (12), the:

$a=\frac{1901.68}{0.25}=7698.37$.

Thus, the value (16) is less than the restriction (15), so the solutions coincide obtained by various methods.

It should be noted that the actual values of prices, represented in the table, have the largest deviation from the planned, equal to 20.54. In turn, the greatest deviation of the optimal prices values from the planned is 17.07.

Thus, the relative price fluctuation has decreased by:

$$
\frac{20.54-17.07}{20.54} \cdot 100 \% \approx 16.9 \% \text {. }
$$

Now, the system of models and methods are increasingly used in scientific studies. So far, however, these systems are used in isolation from each other. As a rule, they are not related to each other neither by the set goal, nor by their indicators, nor by the available resources. Therefore, the effectiveness of using such disparate systems, although better than a completely unsystematic approach, but it does not in any way correspond to the current level of development in science and economic practice.

The experience of many countries shows that to solve the most important and difficult problems of complex systems, it is required not 'ideal' models, methods, but a whole complex of goal-oriented systems, which complement each other: systems of goals, restrictions, priorities, generalizing indicators, models, methods, pilot and adjust programs, measures for their effective implementation, etc.

The development of transformational processes in Ukraine's economy has a significant impact on the life of all regions and businesses and, in particular, iron-ore industry. The instability of the external environment and the low adaptive capacity of enterprises to any market transformations create dangerous conditions for their activities.

The theoretical and methodological issues of the competitive potential formation of the mining enterprises, its structure, organization of use, the development of diagnostic methods, the choice of the direction in the energy potential development have not yet been solved. It is considered to be an urgent problem today.

The process of substantiating the harmonization of methods and models of electric-power consumption systems requires of comparing indicators that cannot be directly compared - the volumes of electric-power supply, zonal electric-power prices. Using the index methods allows to solve such problems. The specificity of the index method is in the fact that in the index, the quantitatively incomparable values are reduced to a certain general unity, which makes them comparable and commensurable (Holovach, Zakhozhai, \& Holovach, 2005).

The index method of factor analysis makes it possible to determine the influence of a significant number of factors linked as the cofactors product or the sum of cofactors products (Holovach, Zakhozhai, \& Holovach, 2005).

The index method of analysis occupies a special place in the process of assessing the effectiveness of the structural components in complex systems.

The development of the economy in general is more and more associated with a structural transformation. This effects on all levels of management, from interna- tional and national to the level of separate enterprises. On each of them, the structural transformation is carried out in accordance with certain criteria. Thus, the criterion for the effectiveness of structural policy at the state level is to ensure national interests, which are determined by the combination of the fundamental interests of the individual, society and the state in the field of economics, in the domestic political, international, defense, information and social spheres, spiritual life and culture, based on the concept of national security.

At the level of individual production systems, structural transformation is aimed to improve the efficiency of resources concentration in very productive units, that is, in those with the greatest ability to create new products and technologies, inventions and patents per unit of costs, accelerate the turnover of funds spent and in general - improving the effectiveness of activity, ensuring financial stability based on the market demands. To satisfy these conditions, the enterprise should understand the specifics of management in a competitive environment, with account of success and risks factors. The improving of knowledge-based management is of primary importance in these conditions.

Despite the fact that the management tools are theoretically known, the practice of applying the relevant knowledge is unsuccessful, in particular, which is caused by the lack of adequate methods for assessing the enterprise actual state (Tkachuk, Kropelnytska, \& Petruniak, 2009ж Dmyterko, 2013).

Thus, the level of efficiency is often represented not by individual, but by average values. When analysing the dynamics of the average level, the task arises to determine the change in the average level under the influence of each of the listed factors. The solution to this task is a system of such interrelated indexes. Conducting of research was based on the data of intraorganizational reporting of mining enterprises. To obtain the necessary analytical information of monitoring, the reporting of general access was used (Derzhavna sluzhba..., 2018; SMIDA, 2018), for calculations of a system of interrelated indexes of variable, fixed composition and structural changes. The overall average efficiency of electric-power consumption depends, on the one hand, on the efficiency of the level of electricpower consumption at the regional mining enterprises $\left(E_{i}\right)$, and on the other, on the share of each of the enterprise's units in total expenses $d_{i}$. The influence of each of these factors is calculated using a system of interrelated indexes of variable, fixed composition and structural changes. In the combinational distribution by regions and industries, the efficiency index of variable composition is calculated by the formula (17):

$$
I^{v . c .}=\frac{\sum\left(\sum\left(E_{1}^{z} d_{1}^{z}\right) d_{1}^{p}\right)}{\sum\left(\sum\left(E_{0}^{z} d_{0}^{z}\right)\right) d_{0}^{p}} .
$$

where:

$E_{i}$ - the efficiency level of electric-power consumption at the regional mining enterprises; $d_{1}{ }^{p}$ - the share of energy resources of separate enterprises in the composition of the region enterprises. 
The index of the fixed composition shows an impact on the average level dynamics of the electric-power consumption efficiency, its changes in certain areas within regions (18):

$$
I^{f . c .}=\frac{\sum\left(\sum\left(E_{1}^{g} d_{1}^{i}\right)\right) d_{1}^{p}}{\sum\left(\sum\left(E_{0}^{g} d_{0}^{g}\right)\right) d_{0}^{p}} .
$$

The index of structural changes of the $1^{\text {st }}$ order shows the impact of structural changes in the energy resources distribution within the regions (19):

$$
I^{\text {v.c. }(z)}=\frac{\sum\left(\sum\left(E_{0}^{z} d_{0}^{z}\right) d_{1}^{p}\right)}{\sum\left(\sum\left(E_{0}^{z} d_{0}^{z}\right)\right) d_{0}^{p}} .
$$

The index of structural changes of the $2^{\text {nd }}$ order shows the impact of structural changes in the energy resources distribution between the regional enterprises.

The influence of certain factors on the effect dynamics of the electric-power consumption can be determined by the method of chained substitutions: the influence of the intensive factor - the efficiency level of electricpower consumption (20):

$$
\Delta V R P_{g}=\left(E_{1}-E_{0}\right) P_{1},
$$

where:

$E_{1}, E_{0}$ - the system efficiency of electric-power consumption in the current and base period, respectively;

$P_{1}$ - the resources of the current period.

The influence of the extensive factor - the volume of energy resources (21):

$V R P_{p}=\left(P_{1}-P_{0}\right) E_{0}$,

where:

$P_{0}$ - the energy resources of the consumption system of the base period.

The patterns of the certain factors influence have been established, which are the basis for the development of measures to increase the efficiency of electric-power consumption. To determine the role of intensive factors for economic growth, the set of production functions is also used, in particular, the method of A.I. Anchishkin, based on the use in calculations of the Cobb-Douglas production function (Yunusi, 2001).

\section{CONCLUSIONS}

The conducted research made it possible to determine the possibility of applying analytical methods to analyse the cost characteristics of electric-power consumption levels at mining enterprises on the basis of the harmonization of the optimization model and index modelling. The Ukrainian enterprises of the iron-ore industry are the main key factor of the Ukraine's economy. The use of information and analytical monitoring methodology, optimization method of the least modules, made it possible to identify certain parameters at which the deviation of the actual cost characteristics from the planned ones is minimal.
The identification of index components made possible to identify the structural changes in the energy resources distribution and to investigate the intensive factors influence on the electric-power consumption level. The practice of applying the proposed approach has confirmed its effectiveness. The formation of models for assessing the cost characteristics of the electric-power consumption levels is the basis for further research in the construction of multifactorial regression and prediction models. The construction of a system with such models will allow to identify the most promising trends in the development of electric-power supply systems at the regional mining enterprises and ensure the rational management by electric-power consumption processes.

\section{ACKNOWLEDGEMENTS}

The author expresses particular gratitude to T.M. Beridze, Candidate of Engineering Sciences, Associate Professor, for consulting assistance in formulation of this scientific article.

\section{REFERENCES}

Bayoumi, E.H.E. (2015). Power electronics in smart grid power transmission systems: a review. International Journal of Industrial Electronics and Drives, 2(2), 98-115. https://doi.org/10.1504/ijied.2015.069784

Burkova, L.A. (2015). Estimation of economic performance of enterprises taking into account the degree of crisis of their financial condition (for example, the ore dressing mills). Kryvyi Rih, Ukraine: Kryvyi Rih National University.

Cherevko, O.V. (2007). Strategy of social and economic development of regions of Ukraine. Kyiv, Ukraine: National Academy of Sciences of Ukraine, Council for the Study of the Productive Forces of Ukraine.

Cherniavskyi, A.V., \& Kulikova, E.O. (2011). Analysis and forecasting of electricity consumption at dairy enterprises. Enerhetyka, Ekolohiia, Liudyna, 310-315.

Derzhavna sluzhba statystyky Ukrainy. (2018). [Online]. Available at: http://www.ukrstat.gov.ua/operativ/oper_new.html

Dmyterko, M.O. (2013). Rehionalni klastery Ukrainy: efektyvnist ikh stvorennia ta perspektyvy rozvytku. [Online]. Available at: http://www.confcontact.com

Dmytryshyn, B.V., \& Hamalii, V.F. (2013). Conceptual approach to modeling the productivity of economic systems based on inter-industry balance. Naukovi Pratsi Kirovohradskoho Natsionalnoho Tekhnichnoho Universytetu. Ekonomichni Nauky, (24), 8-15.

Dzenis, V.O., \& Dzenis, O.O. (2011). Use of cluster analysis in assessing the level of financial and economic potential of the enterprise. Biznes Inform, (2), 61-65.

Farret, F.A., \& Simoes, M.G. (2006). Integration of alternative sources of energy. New Jersey, United States: John Wiley $\&$ Sons Inc. https://doi.org/10.1002/0471755621.ch12

Holovach, A.V., Zakhozhai, V.B., \& Holovach, N.A. (2005). Statystychne zabezpechennia upravlinnia ekonomikoiu: prykladna statystyka. Kyiv, Ukraine: KNEU.

Mareschal, B. (1988). Weight stability intervals in multicriteria decision aid. European Journal of Operational Research, 33(1), 54-64. https://doi.org/10.1016/0377-2217(88)90254-8

Moiseienko, I.P., Revak, I.O., \& Demchyshyn, M.Ya. (2013), Modeling of economic security of the state by parameters of intellectual potential. Aktual'ni Problemy Ekonomiky, (12), 278-285. 
Rozen, V.P., \& Davydenko, L.V. (2010). Neural network modeling of electricity consumption of enterprises of the coal industry. Visnyk KDU imeni Mykhaila Ostrohradskoho, 3(62), 156-160.

Saade, J.J., \& Diab, H.B. (2000). Defuzzification techniques for fuzzy controllers. IEEE Transactions on Systems, Man and Cybernetics, Part B (Cybernetics), 30(1), 223-229. https://doi.org/10.1109/3477.826965

Sinchuk, O.N., Guzov, E.S., Parkhomenko, R.A., \& Rozen, V.P. (2013). Improvement of calculation methods of loads of systems of electricpower supply of ore shafts. Gornyi Zhurnal, (12), 87-90.

Sinchuk, O.M., Boiko, S.M., Sinchuk, I.O., Karamanyts, F.I., Kozakevych, I.A., Baranovska, M. I., \& Yalova, O.M. (2018). Aspects of the problem of applying distributed energy in iron ore enterprises electricity supply systems. Warsaw, Poland: iScience Sp. z.o.o.

Sinchuk, O.N., Likarenko, A.G., Petrychenko, A.A., Zimankov, R.V., \& Shkrabets, F.P. (2016). Hardwareelectrical safety problems with operation of electrotechnical complexes with regulated electric drives in mining area distribution networks up to 1200 V. Technical Electrodynamics, 2016(5), 79-81.

https://doi.org/10.15407/techned2016.05.079
SMIDA. (2018). [Online]. Available at: http://smida.gov.ua/

Stetsenko, I.V. (2010). Modeliuvannia system. Cherkasy, Ukraine: ChDTU.

Sukhorukov, A.I., \& Kharazishvili, Yu.M. (2012). Modeliuvannia ta prohnozuvannia sotsialno-ekonomichnoho rozvytku rehioniv Ukrainy. Kyiv, Ukraine: NISD.

Tkachenko, A.M., \& Marchenko, K.A. (2014). Modern approaches to managing the development of the enterprise. Ekonomika i Rehion, (1), 85-90.

Tkachuk, I., Kropelnytska, S., \& Petruniak, T (2009). Orhanizatsiia vyrobnytstva za klasternoiu modelliu. Ivano-Frankivsk, Ukraine: Prykarpatskyi natsionalnyi universytet imeni Vasylia Stefanyka.

Vasyl'tsiv, T.H. (2008). Ekonomichna bezpeka pidpryiemnytstva Ukrainy: stratehiia ta mekhanizmy zmitsnen. Lviv, Ukraine: Aral.

Yelisieieva, O.K. (2011). Simulation of socio-economic systems management. Dnipropetrovsk, Ukraine: Dnipropetrovsk National University named after Oles Gonchar.

Yunusi, M. (2001). About solutions of one class model equations and its applications. Zurich, Switzerland: GAMM.

Zeleny, M. (1982). Multiple criteria decision making. New York: McGraw-Hill. https://doi.org/10.1007/springerreference 5854

\section{ГАРМОНІЗАЦІЯ СИСТЕМ МОДЕЛЮВАННЯ ОЦІНЮВАННЯ РІВНІВ ЕЛЕКТРОСПОЖИВАННЯ ГІРНИЧОРУДНИХ ПІДПРИЕМСТВ}

\section{I. Сінчук}

Мета. Вивчення системних корпоративних характеристик систем електроспоживання, формування прикладного науково-методичного забезпечення та інструменти економіко-математичного моделювання з метою аналізу й вартісних характеристик електроспоживання.

Методика. Дослідження засноване на використанні законів, закономірностей та категоричного апарату. У процесі наукових досліджень були використані загальні наукові методи досліджень (порівняння, узагальнення, метод аналогій, структурний аналіз та синтез), методи логіко-теоретичного аналізу, спеціальні економікоматематичні методи. Нормативною базою для дослідження були офіційні документи, що відображають та регулюють певні аспекти системи споживання енергії при зборі, обробці та представленні інформації. Як інформаційні джерела використані матеріали наукових конференцій та семінарів, ресурси глобальної інформаційної системи Інтернету, інформація Державної служби статистики України. Теоретичні основи дослідження, що обслуговуються науковими роботами вітчизняних та зарубіжних дослідників у галузі енергозабезпечення в перехідній економіці. Комплекс регресійних та індексних методів та моделей аналізу споживання електроенергії для визначення трансформаційних змін компонентів споживання електричної енергії.

Результати. Проаналізовано параметри споживання електроенергії на залізорудних підприємствах Криворізького регіону. Досліджено процес формування системи моделей для вирішення проблеми оптимізації вартісних характеристик споживання електроенергії. Визначено системні корпоративні характеристики систем енергоспоживання залізорудних підприємств Криворізького регіону. Сформовано інструментарій економічного та математичного моделювання 3 метою аналізу та оцінювання показників вартості систем енергоспоживання. Гармонізація методів моделювання дозволила визначити вартісні характеристики та довести раціональність застосування моделей, розрахувати ефективний розподіл ресурсів, надати рекомендації відповідно до раціональних управлінських рішень щодо формування споживання електроенергії.

Наукова новизна. Запропоновано інноваційний комплексний підхід до формування корпоративних моделей систем електропостачання, що полягає у використанні індексної методології в поєднанні з методами найменших модулів. Це дозволяє оптимізувати витрати електроенергії і забезпечити раціональне управління електроспоживанням.

Практична значимість. Формування корпоративних моделей $є$ основою для подальшого дослідження і побудови багатофакторних регресійних моделей та моделей для прогнозування споживання електроенергії. Практичний досвід використання запропонованої методології довели свою ефективність при прийнятті управлінських рішень з метою забезпечення оптимальних витратних характеристик споживання електроенергії.

Ключові слова: моделювання, споживання електроенергії, показники, ресурси, підприємство

\section{ГАРМОНИЗАЦИЯ СИСТЕМ МОДЕЛИРОВАНИЯ ОЦЕНКИ УРОВНЕЙ ЭЛЕКТРОПОТРЕБЛЕНИЯ ГОРНОРУДНЫХ ПРЕДПРИЯТИЙ}

\section{И. Синчук}

Цель. Изучение корпоративных характеристик систем электроснабжения, формирования прикладного научно-методического обеспечения и инструментария экономико-математического моделирования для анализа и стоимостных характеристик электропотребления. 
Методика. Исследование основано на использовании законов, закономерностей и категорического аппарата. В процессе научных исследований были использованы общие научные методы исследования (сравнение, обобщение, метод аналогий, структурный анализ и синтез), методы логико-теоретического анализа, специальные экономико-математические методы. Нормативной базой для исследования были официальные документы, отражающие и регулирующие определенные аспекты системы потребления энергии при сборе, обработке и представлении информации. Как информационные источники, использованные материалы научных конференций и семинаров, ресурсы глобальной информационной системы Интернета, информация Государственной службы статистики Украины. Теоретические основы исследования, обслуживаемых научными работами отечественных и зарубежных исследователей в области энергообеспечения в переходной экономике. Комплекс регрессионных и индексных методов и моделей анализа потребления электроэнергии для определения трансформационных изменений компонентов потребления электрической энергии.

Результаты. Проанализированы параметры потребления электроэнергии на железорудных предприятиях Криворожского региона. Исследован процесс формирования системы моделей для решения проблемы оптимизации стоимостных характеристик потребления электроэнергии. Определены корпоративные характеристики систем энергопотребления железорудных предприятий Криворожского региона. Сформирован инструментарий моделирования с целью анализа и оценки показателей стоимости систем энергопотребления. Гармонизация методов моделирования позволила определить стоимостные характеристики и доказать рациональность применения моделей, рассчитать эффективное распределение ресурсов, дать рекомендации в соответствии с рациональными управленческими решениями по формированию потребления электроэнергии.

Научная новизна. Предложен инновационный комплексный подход к формированию корпоративных моделей систем электроснабжения заключающийся в использовании методологии индексов в сочетании с методами наименьших модулей, что позволяет оптимизировать затраты электроэнергии и осуществить рациональное управление электропотреблением.

Практическая значимость. Формирование корпоративных моделей является основой для дальнейшего исследования и построения многофакторных регрессионных моделей и моделей для прогнозирования потребления электроэнергии. Практический опыт использования предложенной методологии доказали свою эффективность при принятии управленческих решений с целью обеспечения оптимальных расходных характеристик потребления электроэнергии.

Ключевые слова: моделирование, потребление электроэнергии, показатели, ресурсы, предприятие

\section{ARTICLE INFO}

Received: 12 July 2018

Accepted: 13 November 2018

Available online: 12 December 2018

\section{ABOUT AUTHORS}

Ihor Sinchuk, Candidate of Technical Sciences, Associate Professor of the Department of Automated Electromechanical Systems in Industry and Transport, Kryvyi Rih National University, 11 Matusevycha St, 50027, Kryvyi Rih, Ukraine. E-mail: Beridzet2016@gmail.com 